\title{
Comparative study of glycoproteins in normal individuals and in patients with hypothyroidism and hyperthyroidism
}

\author{
N. Muninathan', P. Mohanalakshmi',** \\ ${ }^{1}$ Research Scientist, Central Research Laboratory, Meenakshi Medical College and Research Institute, Enathur, Kanchipuram, \\ Tamil Nadu, ${ }^{2}$ Associate Professor, Dept. of Biochemistry, Sri Muthukumaran Medical College, Chikkarayapuram, Chennai, \\ Tamil Nadu, India
}

*Corresponding Author:

Email: pmona25@yahoo.co.in

Received: $14^{\text {th }}$ March, 2018

Accepted: $1^{\text {st }}$ May, 2018

\begin{abstract}
Aim: the present study was carried out to compare the glycoproteins in normal individuals and in patients with hypothyroidism and hyperthyroidism.

Materials and Methods: This study was carried out at Meenakshi Medical College \& Research Institute on total 90 individuals, 30 hypothyroid patients, 30 hyperthyroid patients and 30 normal individuals were taken as controls. Each group consisted of both sexes and the participants were between the ages of 25 to 50 years. Various parameters like protein bound fucose, hexose, hexosamine, sialic acid and thyroid function test which include $\mathrm{ft} 3, \mathrm{ft} 4$ and $\mathrm{TSH}$ were measured in all the 90 individuals. The data was collected and analyzed.

Result: Potein bound hexose, sialic acid, fucose and hexosamine decreased in hypothyroid patients when compared to normal individuals, whereas in patients with hyperthyroidism only protein bound hexose and fucose levels increased significantly whereas sialic acid, hexose were decreased when compared to normal individuals.

Conclusion: Serum Glycoproteins can be additional markers to $\mathrm{ft} 3, \mathrm{ft} 4$ and $\mathrm{TSH}$ and aid in diagnosis and management of thyroid disorders.
\end{abstract}

Keywords: Glycoproteins, Thyroid function test, Hyperthyroidism, Hypothyroidism.

\section{Introduction}

Glycoproteins are composed of a protein and a carbohydrate moeity, usually hexose, hexosamine, fucose and sialic acid, covalently linked to their polypeptide chain. Glycoproteins are classified into 3 major classes:

1. $\mathrm{N}$ - linked where the glycosidic linkage is between amide nitrogen and $\mathrm{N}$-acetyl glycosamine (GlcNAcAsn)

2. O- linked where the glycosidic linkage is between hydroxyl group of serine or threonine and $\mathrm{N}$ acetylgalactosamine (GalNAc).

3. Glycoproteins which involves linkage to the carboxyterminal aminoacid of a protein through phoshorylethanolamine joined to the oligosaccharide chain, which is further linked to phosphatidylinositol through glucosamine, so they are known as glycosylphosphatidylinositol or GPI linked glycoproteins. ${ }^{1,2}$

As most of the plasma proteins except albumin are glycoproteins, they perform numerous functions in the body such as hormones, proteins, blood group substances, integral membrane proteins and also regulate the lifespan of proteins by preventing the loss of sialic acid from the oligosaccharide chain of erythrocytes, serve as recognition signals to facilate cell to cell interaction and also stabilize the proteins against denaturation.

In healthy individuals the levels of glycoproteins are within the normal range. These glycoproteins like protein bound hexose, sialic acid, fucose are increased in certain diseases like tuberculosis, diabetes mellitus, cardiovascular and auto immune diseases. ${ }^{1,3}$

Increased glycoproteins levels in various diseases is due to altered glycosylation of the proteins which are secreted. Glycosylation is the common form of posttranslational modification of proteins. The process of glycoslylation play an essential role in metastasis, adhesion and signalling. Most of the cancer biomarkers used are glycoproteins. These glycoproteins which are secreted in the malignant cells reach the bloodstream through common secretory pathway or enter due to shedding of cell membrane as a result of increased protease activity. So these glycoproteins can be used as potential target for the development of cancer biomarkers. ${ }^{4-7}$

Thyroid stimulating hormone is a member of glycoprotein family. TSH exhibits large variations in glycosylation under pathological conditions. TSH glycosylation changes are mostly observed in hypothyroid patients. Prolonged half-life and bioactivity of TSH is noted in hypothyroid patients due to increased glycosylation whereas decreased glycosylation is noted in hyperthyroid patients. Glycosylation changes significantly during oncogenesis. Detection of tumour specific alterations could be potentially useful for cancer diagnosis. ${ }^{8,9}$

More than 200 million people in the world are affected with thyroid diseases. Though many treatment options are available, untreated thyroid disease can cause 
various complications in humans. The thyroid gland is a butterfly shaped gland which is located in the neck just above the trachea.

The hypothalamus secretes thyrotropin releasing hormone (TRH) which acts on anterior pituitary gland and releases thyroid stimulating hormone (TSH). Thyroid stimulating hormone stimulates the thyroid gland and releases two hormones thyroxine and triiodothyronine which known as T4 and T3. Thyroid hormones regulate various functions in the body such as energy homeostasis, growth and metabolism. ${ }^{10}$

Thyroid disorders are classified into two main types:

1. Hypothyroidism

2. Hyperthyroidism

Hypothyroidism is defined as deficiency in the production of thyroid hormone and its action. Hypothyroidism mostly affects women than men and both the sexes are equally affected as age increases. Hypothyroidism can be further classified into primary hypothyroidism and secondary hypothyroidism. Primary hypothyroidism is due to deficit in the synthesis of T3 and $\mathrm{T} 4$, which can be due to intrinsic or extrinsic factor or it is due to inherited defect in the thyroid hormone biosynthesis. The commonest cause for primary hypothyroidism is radiation therapy (I-131).

Secondary hypothyroidismis due to pituitary or hypothalamic disease, as a result there is a deficiency in the production of TSH, TRH or both. The clinical symptoms commonly seen in patients with hypothyroidism are weight gain, lethargy, cold intolerance, hoarness of voice, irregular menstrual cycle and muscle cramps.

Hyperthyroidism is defined as a disease state where there is excessive production of thyroid hormones. It is otherwise called as thyrotoxicosis. Symptoms are fatigue, irritability, weight loss, palpitations, sweating, heat intolerance, goiter. The common cause for hyperthyroidism is grave's disease. ${ }^{10-13}$

\section{Materials and Methods}

The study design is a case control study. After approval from institutional ethical committee, the study was carried out in Meenakshi Medical College and research institute. As mentioned earlier we included 30 hyperthyroid, 30 hypothyroid and 30 normal healthy individuals of both the sexes in the age group of 25 to 50 years. The exclusion criteria in this study were patients with diabetes mellitus, hypertension, liver disease and other systemic illness.

The following parameters were analysed in patients with hyperthyroid, hypothyroid and normal healthy individuals who were taken as controls. Th thyroid function test which includes which includes fT3, fT4 and TSH was done by elisa method.

Estimation of glycoproteins was done by the following methods:-

Hexose - method of Niebes

Hexosamine - method of Wagner

Sialic acid - method of Warren

Fucose - Winzler method.

\section{Statistical Analysis}

The statistical analysis in this study was done by students ' $t$ ' test. Statistical assessment was based on the ' $\mathrm{P}$ ' value. $\mathrm{P}$ value less than 0.05 was considered significant. The data was analyzed using the statistical package IBM SPSS Statistics-20.

\section{Results}

Table 1: Comparison of serum thyroid profile between normal and hypothyroid subjects

\begin{tabular}{|l|c|c|c|c|c|}
\hline \multicolumn{1}{|c|}{ Particulars } & Control -30 & Hypothyroid -30 & "t'" & df & Sig \\
\hline fT3 $(\mathrm{ng} / \mathrm{mL})$ & $2.2 \pm 0.65$ & $1.42 \pm 0.12^{*}$ & 6.463 & 58 & $\mathrm{P}<0.001$ \\
\hline $\mathrm{fT} 4(\mathrm{pg} / \mathrm{dL})$ & $1.6 \pm 0.15$ & $0.6 \pm 0.03^{*}$ & 35.805 & 58 & $\mathrm{P}<0.001$ \\
\hline TSH $(\mu \mathrm{IU} / \mathrm{mL})$ & $0.60 \pm 0.26$ & $19.2 \pm 2.97^{*}$ & 34.171 & 58 & $\mathrm{P}<0.001$ \\
\hline
\end{tabular}

Table 2: Comparison of serum thyroid profile between normal and hyperthyroid subjects

\begin{tabular}{|l|c|c|c|c|c|}
\hline \multicolumn{1}{|c|}{ Particulars } & Control -30 & Hyperthyroid-30 & "t" & df & Sig. \\
\hline fT3 $(\mathrm{ng} / \mathrm{mL})$ & $2.2 \pm 0.65$ & $6.1 \pm 0.62^{*}$ & 23.780 & 58 & $\mathrm{P}<0.001$ \\
\hline $\mathrm{fT} 4(\mathrm{pg} / \mathrm{dL})$ & $1.6 \pm 0.15$ & $2.9 \pm 0.34^{*}$ & 20.504 & 58 & $\mathrm{P}<0.001$ \\
\hline $\mathrm{TSH}(\mu \mathrm{IU} / \mathrm{mL})$ & $0.60 \pm 0.26$ & $0.01 \pm 0.001 *$ & 12.429 & 58 & $\mathrm{P}<0.001$ \\
\hline
\end{tabular}

Table 3: Comparison of glycoproteins between normal and hypothyroid patients

\begin{tabular}{|l|c|c|c|c|c|}
\hline \multicolumn{1}{|c|}{ Particulars } & Control & Hypothyroidism & "t & df & Sig \\
\hline Protein sialic acid & $1.6 \pm 0.11$ & $2.6 \pm 0.27^{\text {a }}$ & 18.786 & 58 & $\mathrm{P}<0.001$ \\
\hline Protein Fucose & $6.1 \pm 0.65$ & $1.0 \pm 0.08^{\mathrm{a} *}$ & 42.653 & 58 & $\mathrm{P}<0.001$ \\
\hline Protein hexose & $2.7 \pm 0.33$ & $3.6 \pm 0.35^{\text {a }}$ & 10.248 & 58 & $\mathrm{P}<0.001$ \\
\hline Protein hexamine & $1.4 \pm 0.15$ & $0.9 \pm 0.11^{\mathrm{a} *}$ & 14.723 & 58 & $\mathrm{P}<0.001$ \\
\hline
\end{tabular}


Table 4: Comparison of glycoproteins between normal and hyperthyroid patients

\begin{tabular}{|l|c|c|c|c|c|}
\hline \multicolumn{1}{|c|}{ Particulars } & Control & Hyperthyroidism & "t" & df & Sig \\
\hline Protein sialic acid & $1.6 \pm 0.11$ & $1.1 \pm 0.13^{\mathrm{b} *}$ & 16.082 & 58 & $\mathrm{P}<0.001$ \\
\hline Protein Fucose & $6.1 \pm 0.65$ & $8.9 \pm 0.76^{\mathrm{b} *}$ & 15.335 & 58 & $\mathrm{P}<0.001$ \\
\hline Protein hexose & $2.7 \pm 0.33$ & $1.8 \pm 0.24^{\mathrm{b} *}$ & 12.081 & 58 & $\mathrm{P}<0.001$ \\
\hline Protein hexamine & $1.4 \pm 0.15$ & $1.6 \pm 0.18^{\mathrm{b} *}$ & 2.434 & 58 & $\mathrm{P}<0.05$ \\
\hline
\end{tabular}

\section{Discussion}

In our study as per table 1 serum fT3 levels $(\mathrm{P}<0.001)$ and $\mathrm{fT} 4$ levels $(\mathrm{P}<0.001)$ were significantly decreased but the serum TSH levels $(\mathrm{P}<0.000)$ increased significantly in hypothyroid patients when compared with normal subject.

As per table 2 serum fT3 levels $(\mathrm{P}<0.001)$ and fT4 levels $(\mathrm{P}<0.001)$ were significantly increased in hyperthyroid patients when compared to normal subjects. But serum TSH levels decreased significantly in hyperthyroid patients when compared with normal subjects.

In our study as per table 3, serum level of protein bound-fucose and protein bound-hexamine are decreased compared to normal subjects but, protein bounded sialic acid, protein bound-hexose levels were significantly increased in hypothyroidism patient when compared with normal subjects.

As per table 4 protein bound-sialic acid, and protein bound-hexose are decreased but the protein boundfucose and protein bound-hexamine are increased in hyperthyroid patients when compared to controls.

As per study, the levels of sialic acid and hexose are increased in patients with hypothyroidism. As glycoproteins are major constituents of integral membrane, any disruption of the membrane can cause release of the glycoproteins which could be the probable cause for the increase of sialic acid and hexose in hypothyroidism.

In hyperthyroid patients we observed increased levels of fucose and hexamine which could be due to depolymerisation of the glycoproteins.

According to Patel et al, the levels of hexose and sialic acid increased significantly in hypothyroid conditions. $^{14}$

Study by Kumari $\mathrm{N}$ et al also showed increased sialic acid levels in hypothyroidism and decreased levels of sialic acid in patients with hyperthyroidism and the study also observed that these glycoproteins sialic acid and fucose along with adenosine deaminase can be used as a marker in thyroid disorders. ${ }^{15}$

The following studies shows increased glycoproteins levels in hypothyroidism and our study also correlated with their results.

\section{Conclusion}

In our study, patients with hypothyroidism had increased levels of sialic acid and hexose and decreased levels of fucose and hexosamine. But in hyperthyroid patients we found increased levels of fucose and hexosamine and decreased levels of sialic acid and hexose.

We conclude that serum glycoproteins can be additional markers to $\mathrm{fT}_{3}$ and $\mathrm{fT}_{4}$ and $\mathrm{TSH}$ and aid in diagnosis, monitoring and in the management of thyroid disorders.

\section{References}

1. Pierce JG, Parsons TF, Glycoprotein hormones: structure and function, Ann. Rev. Biochem. 1981;50:465-495.

2. Pankaja Naik, Textbook of Biochemistry, 3th edition, p.40.

3. Harper's illustrated biochemistry, $28^{\text {th }}$ edition, pp.509510.

4. Kumar A, Nadig M, Patra V, Srivastava DN, Verma K, Bal CS. Adrenal and renal metastases from follicular thyroid cancer. Br J Radiol, 2005, 78:1038-41.

5. Pierce M, Arango J. 1986. Rous sarcoma virustransformed baby hamster kidney cells express higher levels of asparagine-linked tri- and tetraantennary glycopeptides containing [GlcNAc-beta $(1,6)$ Manalpha(1,6)Man] and poly-N-acetyllactosamine sequences than baby hamster kidney cells. J Biol Chem, 261:10772-10777.

6. Ohyama C, Hosono M, Nitta K, Oh-eda M, Yoshikawa K, Habuchi T, Arai Y, Fukuda M. 2004. Carbohydrate structure and differential binding of prostate specific antigen to Maackia amurensis lectin between prostate cancer and benign prostate hypertrophy. Glycobiology. 14:671-679.

7. Gomaa AI, Khan SA, Leen EL, Waked I, TaylorRobinson SD. 2009.Diagnosis of hepatocellular carcinoma. World J Gastroenterol 15:1301-1314.

8. Dennis JW, Laferte S, Waghorne C, Breitman ML, Kerbel RS. 1987. Beta 1-6 branching of Asn-linked oligosaccharides is directly associated with metastasis. Science. 236:582-585.

9. Drake RR, Schwegler EE, Malik G, Diaz J, Block T, Mehta A, Semmes OJ.2006. Lectin capture strategies combined with mass spectrometry for the discovery of serum glycoprotein biomarkers. Mol Cell Proteomics, 5:1957-1967.

10. Teitz's Textbook of clinical biochemistry and molecular diagnostics, $4^{\text {th }}$ edition, pp.2057-2060.

11. Simon H. "Hypothyroidism". University of Maryland Medical Medical System, 22 S. Greene Street, Baltimore, MD 21201. www.intechopen.com

12. Department of Pathology. "Pituitary Gland -Diseases/Syndromes". Virginia Commonwealth University. https://es.scribd.com/document/172362621.

13. Faculty of Medicine \& Dentistry. "Course-Based Physical Examination - Endocrinology - Endocrinology Objectives (Thyroid Exam)". Undergraduate Medical Education. University of Alberta. 2006. http://www.med.ualberta.ca/education/ugme/clinicaled12/ clinskills_endocrinology.

14. Patel PS, Baxi BR, Adhvarya SG, Balar DB, Individual and combined usefulness of lipid associated sialic acid, 
mucoid proteins and hexose as tumour marker in breast carcinoma. Cancer let. Jun 15;51(3):203-208.

15. Ullal Harshini Devi, Vijay .R, Suchetha Kumari .N, Sathyavathi R Alva. Estimation of sialic acid, l-fucose and adenosine deaminase level in hypo and

hyperthyroidism. Asian J Pharm Clin Res, Vol 5, Suppl 2, 2012, 211-214.

How to cite this article: Muninathan $\mathrm{N}$, Mohanalakshmi P. Comparative study of glycoproteins in normal individuals and in patients with hypothyroidism and hyperthyroidism. Int $\mathrm{J}$ Clin Biochem Res. 2018;5(3):415-418. 